\title{
PERANCANGAN KAMPANYE SOSIAL UNTUK MENINGKATKAN KESADARAN REMAJA MENGENAI RASISME DI INDONESIA
}

\author{
Restu Hendriyani Magh'firoh ${ }^{1}$ \\ Benny Rahmawan Noviadji ${ }^{2}$ \\ Yohanes Halim ${ }^{3}$ \\ Institut Informatika Indonesia, Surabaya ${ }^{l}$ \\ restu@ikado.ac.id
}

\begin{abstract}
Abstrak
Rasisme didefinisikan sebagai kumpulan dari berbagai ide yang memiliki potensi untuk membentuk suatu prasangka buruk pada suatu kelompok. Dimana permasalahannya di Indonesia masih ditemukan tindakan rasisme di media online dan kadang juga terjadi secara terselubung dan didepan mata. Perancangan kampanye ini dibuat untuk membantu meningkatkan kesadaran remaja awal hingga akhir kisaran umur 16-24 tahun agar bisa mengurangi tindakan rasisme di Indonesia. Pembuatan karya ini dimulai dari riset data menggunakan teknik observasi dengan studi komperator dan kompetitor, lalu melakukan wawancara untuk mencari perbedaan baik secara teknis dan desain. Kemudian untuk proses perancangannya dimulai dari melakukan pengumpulan data dari wawancara dan observasi lalu menyusun konten isi atau topik dari Instagram, kemudian membuat sketsa hingga hasil final dari konsep art untuk setiap postingan Instagram, dan yang terakhir pembuatan media pendukung untuk mempromosikan kampanye ini. Dari hasil perancangan ini menghasilkan sebuah kampanye berupa konsep art dan juga informasi seputar rasisme yang diupload di sosial media Instagram dan media pendukung berupa merchandise seperti kaos, sticker set, tumbler, masker, Notebook, Bucket hat, Totebag, Standing Pouch dan juga media pendukung yang diterapkan di sosial media seperti Story Instagram, dan Filter yang berguna juga sebagai media promosi dari kampanye ini. Dengan adanya kampanye ini diharapkan bisa membantu mengurangi adanya perilaku rasisme di Indonesia.
\end{abstract}

Kata kunci: Rasisme, Konsep art, Kampanye sosial 


\begin{abstract}
Racism is defined as a collection of various ideas and beliefs that have the potential to form a prejudice against a group. Where the problem is in Indonesia, there are still acts of racism in online media and sometimes they also happen covertly and in plain sight. The design of this campaign was made to help raise awareness of young people from the beginning to the end of the age range of 16-24 years in order to reduce acts of racism in Indonesia. In making this work, starting from data research using observation techniques with comparative and competitor studies, then also conducting interviews to look for differences in both technical and design. Then the design process starts from collecting data from interviews and observations then compiling content or topics from Instagram, then sketching to the final result of concept art for each Instagram post, and finally making supporting media to promote this campaign. From the results of this design, it produces a campaign in the form of concept art and also information about racism that is uploaded on social media Instagram and supporting media in the form of merchandise such as t-shirts, sticker sets, tumblers, masks, Notebooks, Bucket hats, Totebags, Standing Pouches and also supporting media that applied to social media such as Instagram Stories, and filters which are also useful as a promotional medium for this campaign. With this campaign, the author hopes to help reduce racism in Indonesia.
\end{abstract}

Key words: Racism, Concept art, Social campaign

\title{
PENDAHULUAN
}

Indonesia merupakan negara yang indah dan unik, disini tidak hanya terdapat keragaman aneka macam hayati saja, melainkan memiliki berbagai jenis suku dan budaya yang jumlahnya tidak sedikit. Berbicara mengenai penduduk yang ada di Indonesia menurut situs Indonesia.go.id berdasarkan data sensus tahun 2010, suku yang paling banyak ada di negara Indonesia adalah suku jawa yaitu sebesar $40,2 \%$, Sunda yaitu sebesar $15,5 \%$ dari populasi yang ada di Indonesia, lalu yang ketiga ada suku Batak yang terdapat di daerah provinsi Sumatra Utara yaitu sebesar 3,6\% dari populasi yang ada di Indonesia, kemudian ada suku Madura yang merupakan populasi ke-5 yang terbesar yaitu sebanyak 3,03\% dari populasi yang ada di Indonesia, dan masih banyak lagi. (Indonesia.go.id, 2018).

Saat ini, di era modern sering terjadi adanya kasus rasisme tidak hanya di negara kecil atau besar, tanpa kita sadari perilaku rasisme sudah melekat dan selalu berdampingan di kehidupan atau lingkungan kita sehari-hari, banyak perilaku tidak 
menyenangkan dari tindakan rasisme ini seperti perbedaan pelayanan, perbedaan cara bicara, cara menanggapi dan lain lain hanya karena berbeda warna kulit. Salah satunya di Indonesia sebagai negara yang memiliki banyak suku dan perbedaan adat istiadat memungkinkan juga terjadi rasisme. Untuk saat ini khususnya di era digital, masih banyak pengguna sosmed secara sadar memberikan komentarkomentar yang berisi ujaran kebencian dengan sengaja menghina atau mencela dan ditujukan kepada orang-orang tertentu. Rasisme tidak hanya sering ditemukan di sosial media, yang sekarang sedang ramai menjadi perbincangan yaitu Asian hate dimana pada fenomena ini orang-orang yang merupakan keturunan Asia maupun orang Asia yang ada di negara barat maupun Eropa mengalami kekerasan akibat dari panedmi virus covid dari China.

Menurut Karo Penmas Divisi Humas Mabes Polri Brigjen Dedi Prasetyo dalam diskusi publik dan media SETARA mengatakan bahwa dari bulan Januari hingga September 2019 telah terjadi 22 laporan kasus mengenai rasisme di sosial media kepada polisi. Menurut Dedi tren ini akan meningkat dari tahun ke tahun (Merdeka.com, 2019). Kemudian pengguna sosmed di Indonesia menurut "Digital Around The World 2020" dari 272 juta penduduk , 160 juta sudah menggunakan sosial media yang dimana posisi kedua diduduki oleh pengguna media sosial berusia 18 hingga 24 tahun dan pada urutan ketiga ditempati rentang usia 13 hingga 17 tahun, berada dan jumlahnya di bawah 10\% serta didominasi perempuan. (Kompas.tv,2020).

Maka dari itu perlu adanya diskusi positif antara remaja dengan orang tua, agar remaja mampu memperdayakan mereka sendiri untuk melawan rasisme selain itu diperlukannya juga kesadaran diri pada remaja tersebut agar bisa memberikan dampak yang positif bagi lingkungannya. Demi terciptanya hal tersebut, maka perlu adanya suatu tindakan untuk menyadarkan masyarakat luas khususnya remaja itu sendiri agar bisa mengurangi atau mencegah tindakan rasisme seperti kasuskasus yang sudah terjadi di Indonesia. Oleh sebab itu penelitian ini bertujuan membuat sebuah media yang bisa mengajak secara tidak langsung serta menyadarkan khususnya bagi masyarakat luas khususnya para remaja. Media yang digunakan berupa konsep art yang hasil eksekusinya berupa ilustrasi digital yang menampilkan gaya bahasa, dan ilustrasi yang memiliki nilai pesan (komunikatif) 
dan nilai seni (estetis). Ilustrasi digital digunakan dikarenakan selain sering terjadi rasisme di sosmed, kampanye yang dilakukan di sosial media apabila hanya menampilkan teks, dan bermain pada font saja akan kurang mengena atau menyentuh bagi target audience. Maka dari itu dengan adanya menampilkan konsep art (ilustrasi digital) berbasis vektor yang dipadukan dengan teks di postingan maka diharapkan bisa membantu target audience berimajinasi /membayangkan.

\section{KAJIAN TEORI}

\section{Pengertian Ras}

Ras seperti yang tercantum di KBBI (Kamus Besar Bahasa Indonesia) merupakan suatu penggolongan bangsa berdasarkan ciri fisik (kbbi.co.id). Kemudian menurut Daljoeni ras merupakan suatu kategori tertentu yang dimana ditandai oleh karakter fisik seperti tekstur rambut, warna kulit, lipatan mata dan pengelompokan manusia berdasarkan biologis seperti kaukasoid, Australoid, dan Indian. Jadi ras merupakan suatu penggolongan atau pengelompokan yang berdasarkan ciri biologis maupun fisik (seputarpengetahuan.co.id, 2017).

\section{Pengertian Rasisme}

Menurut National Geographic Indonesia, Rasisme muncul karena adanya suatu pembentukan sebuah ide yang dimana ide tersebut memiliki alasan dan tujuan tertentu. Jadi rasisme didefinisikan sebagai sekumpulan dari berbagai ide serta kepercayaan yang memiliki potensi untuk membentuk suatu prasangka buruk yang pada akhirnya bisa membawa perilaku negatif terhadap kelompok masyarakat tertentu. Perilaku negatif yang muncul adalah diskriminasi (nationalgeographic.grid.id, 2020).

Rasisme sendiri dibagi menjadi dua yaitu:

1) Rasisme Terbuka / Overt

Rasisme atau yang disebut dengan istilah overt merupakan tindakan rasisme yang melibatkan interaksi antar individu atau kelompok yang menggunakan tindakan kekerasan baik secara fisik maupun secara psikologis. 


\section{2) Rasisme Tertutup/ Covert}

Rasisme tertutup atau yang disebut dengan covert merupakan sebuah tindakan rasisme yang terlembaga, bisa dalam berupa bentuk kebijakan, norma yang berkembang, atau sistem kelembagaan negara dan masyarakat yang tidak adil dan seimbang.

\section{Mengatasi Rasisme}

Aktivitas upaya untuk mengakhiri rasisme merupakan sebuah tindakan yang sangat positif, terlebih perlakuan tersebut muncul dari dalam diri individu itu sendiri maupun dilakukan secara kolektif. Frans Boas mendorong pemahaman demokratis tentang budaya dan ras yang menghormati perbedaan yang satu dengan lainnya sehingga tidak akan ada satu kelompok yang dianggap atau menganggap dirinya lebih tinggi atau paling unggul dari yang lain. Pada Individu, dalam mengatasi sebuah tindakan atau perilaku serta perspektif rasis dapat dimulai dengan cara mengubah suatu pandangan serta jagat pikir individu tersebut. Setiap dari individu sendiri harus bisa menetralisir konsep tentang diri dan lian, dan mulai memperlakukan setiap orang secara setara - tanpa peduli apa pun warna kulit mereka. Kemudian pada tingkat atau lingkungan organisasi dan masyarakat juga harus bisa menetralisir dan mulai memberlakukan setiap orang dengan setara tanpa peduli apapun dengan warna kulit mereka (theconversation.com, 2020).

\section{Pengertian Remaja}

Usia remaja menurut WHO adalah mulai dari umur adalah 12 sampai 24 tahun. Masa remaja itu diasosiasikan dengan masa transisi dari anak-anak menuju dewasa selain mengalami kematangan fisik, remaja juga akan mengalami tahapan menuju kemandirian sosial dan ekonomi, membangun identitas, mampu membangun skill untuk kehidupan dimasa yang akan datang serta mampu untuk bernegosiasi (abstract reasoning WHO,2015). Kemudian karakteristik remaja menurut Krori (2011) menyatakan bahwa perubahan sosial yang penting pada masa remaja mencakup meningkatnya pengaruh teman sebaya (peer group), pola perilaku sosial yang lebih matang, pembuatan kelompok sosial yang baru, dan munculnya nilai-nilai baru dalam memilih teman dan pemimpin serta nilai dalam penerimaan sosial (idfebui.org, 2017). Melihat dari perkembangan 
karakteristik remaja diatas, dapat diketahui bahwa apabila memberikan hal positif terhadap suatu individu maka individu tersebut bisa menyebarkan hal positif tersebut kepada individu lainnya secara tidak langsung terutama pada teman-teman terdekatnya.

\section{Pengertian Kampanye}

Kampanye menurut Cangara (2011) adalah sebuah aktivitas komunikasi yang dimana memiliki tujuan untuk mempengaruhi orang lain agar ia memiliki wawasan, sikap, dan perilaku. Dimana hal tersebut sesuai dengan apa yang diinginkan oleh penyebar atau pemberi informasi (kajianpustaka.com, 2019). Menurut Venus (2004), kampanye sosial merupakan sebuah kampanye yang dimana berfungsi untuk mengkomunikasikan pesan-pesan tentang masalah sosial kemasyarakatan, dana bersifat non komersil. Serta memiliki tujuan utama untuk menyadarkan masyarakat akan gejala sosial yang terjadi (kajianpustaka.com, 2019).

Menurut Gregory (2010) Proses penyampaian sebuah pesan atau informasi dalam komunikasi kampanye dilakukan melalui 3 tahap berikut (kajianpustaka.com, 2019):

1) Awareness: dimana publik dilibatkan dalam proses kognitif pada pengertian yang baru. Pada tahap ini merupakan tahap awal yang dimana bertujuan untuk mendapatkan perhatian publik dengan memberikan informasi dan pengetahuan yang dapat menarik publik untuk berpikir lebih jauh tentang suatu permasalahan.

2) Attitude and Opinion: merupakan sebuah tahap untuk membentuk sebuah kebiasaan atau pandangan-pandangan tertentu terhadap suatu objek permasalahan. Perlu diketahui bahwa Attitude berfokus pada reaksi yang ditimbulkan pada penerima informasi tersebut. Entah berupa penerimaan, ketertarikan, dan penolakan.

3) Behaviour, menarik publik untuk melakukan suatu tindakan, biasa disebut dengan konatif. Hal tersebut dilakukan dengan mempromosikan suatu respon yang diinginkan dengan melibatkan tindakan yang harus dilakukan. 


\section{Teori Desain Komunikasi Visual}

Menurut DGI Desain komunikasi visual adalah ilmu yang mempelajari konsep komunikasi dan ungkapan daya kreatif, yang diaplikasikan dalam berbagai media komunikasi visual dengan mengolah elemen desain grafis terdiri dari gambar (ilustrasi), huruf, warna, komposisi dan layout (dgi.id, 2007).

\section{Pengertian Ilustrasi}

Ilustrasi adalah sebuah kata yang berasal dari bahasa Belanda ilustratie yang memiliki arti suatu hiasan dengan gambar. Secara terminologi ilustrasi merupakan suatu gambar yang memiliki fungsi sebagai sarana untuk menjelaskan suatu kejadian. Menurut Soedarso menyatakan bahwa ilustrasi adalah sebuah gambar yang melukiskan tujuan untuk memberi penjelasan dan menggiring sebuah pemahaman. Menurut KBBI (Kamus Besar Bahasa Indonesia) ilustrasi mengandung makna sebuah gambar yang menjelaskan isi dari suatu buku atau menjelaskan sebuah tulisan sehingga membantu pembaca dalam memainkan imajinasinya untuk mengartikan tulisan lewat sebuah gambar.

\section{Pengertian Layout}

Layout adalah penempatan dari elemen desain yang berhubungan ke dalam sebuah bidang yang berguna untuk mendukung pesan maupun konten yang sedang dibawanya. Layout memiliki tugas penting yaitu menampilkan sebuah elemen gambar dan teks agar menjadi komunikatif dan memudahkan pembaca untuk mengerti informasi apa yang disampaikan. (Rustan,2020:10-11).

\section{Pengertian Tipografi}

Menurut Danton Sihombing dalam Buku "Tipografi Dalam Desain Grafis". Bahwa Tipografi merupakan suatu representasi visual dari sebuah bentuk komunikasi verbal dan merupakan suatu properti visual yang pokok dan efektif . Tipografi memiliki sebuah peran yaitu untuk dapat melakukan komunikasi tentang ide atau informasi dari bacaan atau halaman tersebut menuju ke pembaca (seputarilmu.com, 2020). 


\section{Pengertian Warna}

Warna merupakan salah satu unsur penting dalam sebuah obyek desain Warna merupakan salah satu elemen yang dapat menarik perhatian, meningkatkan mood, dan juga menggambarkan citra perusahaan, dan lain-lainnya. Apabila kita salah dalam sebuah pemilihan warna, hal tersebut akan menghilangkan minat untuk membaca. Warna dibagi menjadi 3 warna Primer, Sekunder dan Tersier.(Lia Anggriani.S dam Kirana Nathalia,2014: 37-40)

\section{Pengertian Konsep Art}

Konsep art merupakan suatu bentuk illustrasi yang dimana memiliki tujuan untuk menyampaikan sebuah representasi dari sebuah desain, ide atau mood. Dalam pembuatannya konsep art menggunaan dari berbagai perangkat lunak atau software seperti photoshop, adobe illustrator, painter dan lain-lain (carrotacademy.com, 2013).

\section{Pengertian Vector}

Karya seni vektor adalah istilah yang menggambarkan karya seni yang dibuat dengan menggunakan software seperti Adobe Illustrator. Karya seni vektor dibangun dari grafik vektor, yaitu gambar yang dibuat dengan rumus matematika. Sebagai perbandingan, seni raster (disebut juga sebagai karya bitmap atau gambar raster) dibuat berdasarkan pixel warna lalu apabila kita memperbesar karya seni raster atau bitmaps maka gambar hasil seni raster akan menjadi pecah. Berbeda dengan seni vektor, apabila kita dapat memperbesar seni vektor ke ukuran berapa pun itu tidak mempengaruhi kualitas gambarnya. (adobe.com).

\section{METODE PENELITIAN}

Pada perancangan media utama berupa kampanye sosial di Instagram untuk remaja umur 16-24 tahun terdapat dua metode. Yang pertama ada data primer, yaitu melakukan observasi terhadap kampanye sosial yang ada di sosial media khususnya Instagram dan juga melakukan wawancara kepada guru Sosiologi SMA dan Dosen Sosiologi. Kemudian data Sekunder yaitu dengan mencari data- data yang terdapat di jurnal, artikel atau buku-buku yang sekiranya bisa membantu dalam melakukan perancangan media utama. 


\section{METODE PAERANCANGAN}

Media yang akan digunakan untuk proses perancangan tugas akhir ini yaitu ilustrasi digital yang diaplikasikan ke dalam sosial media Instagram mengingat banyaknya rasisme yang terjadi di sosmed yang menjadi media utama kampanye sosial serta media pendukung yang lainnya.

\section{Penjelasan Tahap 1}

Setelah mengumpulkan data - data sang penulis melakukan brief untuk mengetahui proyek secara menyeluruh dan tentunya mencakup hal-hal yang penting seperti ukuran gambar yang digunakan, biaya, cara agar perancangan ini bisa sampai ke target audience dan masih banyak lagi. seorang ilustrator dituntut untuk harus mengerti dan memahami brief mengenai siapa target audiens dan tenggat waktu / deadline.

\section{Penjelasan Tahap 2}

Setelah semua sketsa dan proses digital sudah dibuat, maka tahap berikutnya adalah melakukan pemilihan warna yang menarik. Pemilihan warna serta komposisi warna yang menarik bertujuan untuk menarik minat target audience untuk melihatnya. Dengan menampilkan desain yang menarik serta warna yang mendukung pada konsep art agar bisa diterapkan di media pendukung maupun media utama

\section{Penjelasan Tahap 3}

Kemudian setelah menentukan pemilihan warna dan komposisinya tahap selanjutnya penulis membuat dan merancang media- media pendukungnya namun tidak hanya media pendukung yang akan diselesaikan media promosi juga akan dikerjakan pada tahap ini. Dimana media promosi yang dicari adalah media yang paling efektif pada minat target audience untuk mendukung agar konsep art ini sampai kepada target audience. Maka dari itu penulis merancang sosial media sebagai dari sebuah media untuk profiling.

\section{HASIL DAN PEMBAHASAN}

Perancangan ini dibuat dalam bentuk kampanye sosial yang nantinya akan dipublikasikan kedalam sosial media Instagram dengan nama "KITASAMA" 
diambil dari kata "kita" dan "sama"yang mengartikan bahwa meskipun secara fisik tampilan kita berbeda akan tetapi didalam tubuh kita semua sama seperti kerangka, dan warna darah. Didalam media ini tidak hanya menampilkan tulisan font mengenai seputar rasisme akan tetapi adanya elemen utama yang menjadi pembeda didalam media ini yaitu konsep art yang digunakan untuk menggambarkan topik yang dibawa.

\section{Batasan Desain}

Perancangan kampanye sosial dengan konsep art ini menggunakan teknik ilustrasi vektor maupun digital ilustrasi yang memberikan edukasi mengenai rasisme agar masyarakat luas khususnya remaja sadar. Konsep art yang akan dibuat berupa ilustrasi digital vector yang dipadukan dengan teks yang berisi tentang kampanye dan sedikit edukasi mengenai rasisme itu sendiri lalu dalam proses penguploadannya ada di jam-jam tertentu yaitu pukul 11-12 siang dan pukul 7-9 malam dikarenakan pengguna Instagram lebih banyak di Smartphone / Handphone jadi kemungkinan sedikit untuk bisa dilihat target audience saat bekerja dan agar bisa dilihat oleh target audience yaitu upload di hari Senin, Rabu, dan Kamis. Kemudian untuk postingan / feed instagram warna yang digunakan merupakan warna yang dominan full colour agar bisa menarik dan eye catching bagi target audience. seperti warna ungu yang melambangkan keakraban, kemudian warna kuning memberikan harapan dan bahagia, kemudian warna hijau yang mengartikan keseimbangan.

Logo, menggunakan warna kulit sesuai dengan tema yang diangkat yaitu rasisme. Untuk jenis font yang digunakan ada 2 yaitu Open Sans sebagai penulisan isi dari topik yang diangkat dan juga Bebas Neue sebagai penulisan judul pada postingan Instagram agar lebih jelas apabila diterapkan kedalam media sosial sebagai media utama, kemudian untuk postingan dari Instagram dibagi menjadi 3 tahap yang pertama tahap penjelasan rasisme beserta fenomenanya, kemudian tahap kedua lebih mengarah dampak dari rasisme tersebut dan sesi terakhir yaitu mengenai upaya menanggulangi perbuatan rasisme. Untuk ukuran gambar yang digunakan dalam media sosial Instagram adalah ukuran 1080px X 1080px. 


\section{Penyajian Perancangan}

Perancangan konsep art ini dipublikasikan di sosial media seperti Instagram yang dimana output dari karya ini berupa digital ilustrasi menyindir perilaku rasisme dan dampak dari rasisme yang telah dilakukan oleh pengguna media sosial maupun diluar media sosial. Lalu selain postingan instagram berupa digital ilustrasi yang menyindir konsep art ini natinya juga akan ditambahkan sedikit teks mengenai informasi yang berhubungan dengan rasisme. Untuk penjelasan mengenai rasisme akan ditaruh di slide selanjutnya, jadi target audience bisa swipe left untuk penjelasan lebih lengkap mengenai pengetahuan yang berhubungan dengan rasisme. Peneliti berencana membuat postingan karya yang dimana untuk 1 pos terdiri dari 2 sampai 4 slide yang bisa di swipe left untuk melihatnya. Lalu pada perancangan ini peneliti telah membuat 3 tema yaitu yang akan menjadi bahan atau topik untuk dipublikasikan kedalam media sosial Instagram.

Berikut merupakan tampilan dari kampanye sosial "KITASAMA":

Sketsa logo yang terpilih menggunakan sketsa tersebut dengan alasan karena bentuk lingkaran memiliki makna untuk saling menjaga dan melindungi demi terciptanya suatu keharmonisan ditengah masyarakat. Lalu arti lingkaran juga memiliki arti bahwa rasisme tidak bisa hilang atau diputus, hanya bisa dikurangin kadarnya dikarenakan adanya masyarakat multikultural.

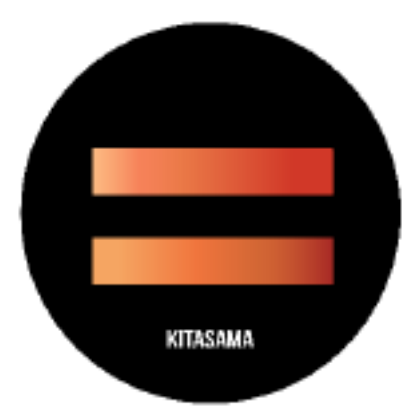

Gambar 1. Gambar Sketsa Logo

Sumber: Dokumen Penulis 


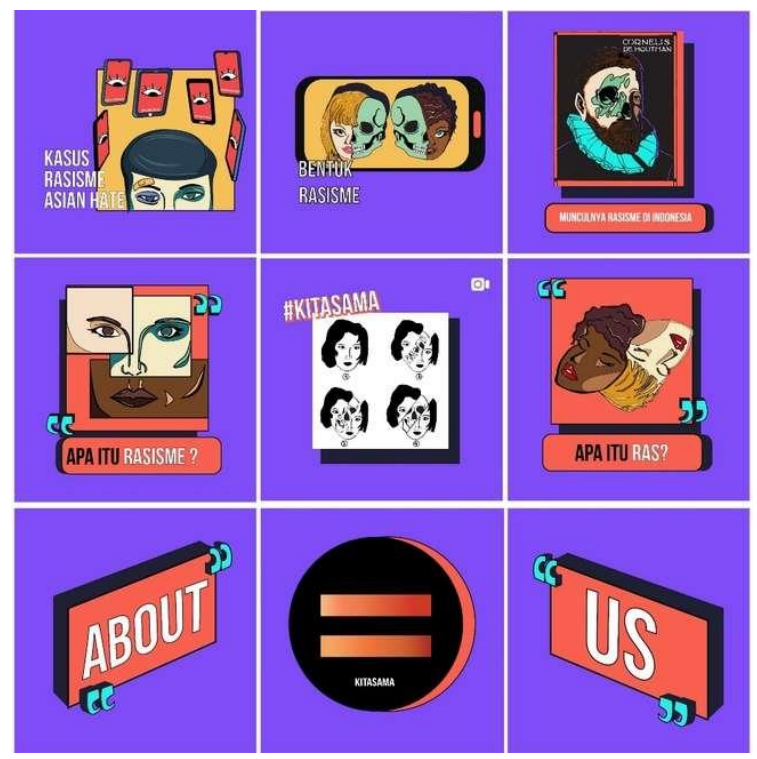

Gambar 2. Gambar desain feed Instagram feed 1-9 Sumber: Dokumentasi Penulis

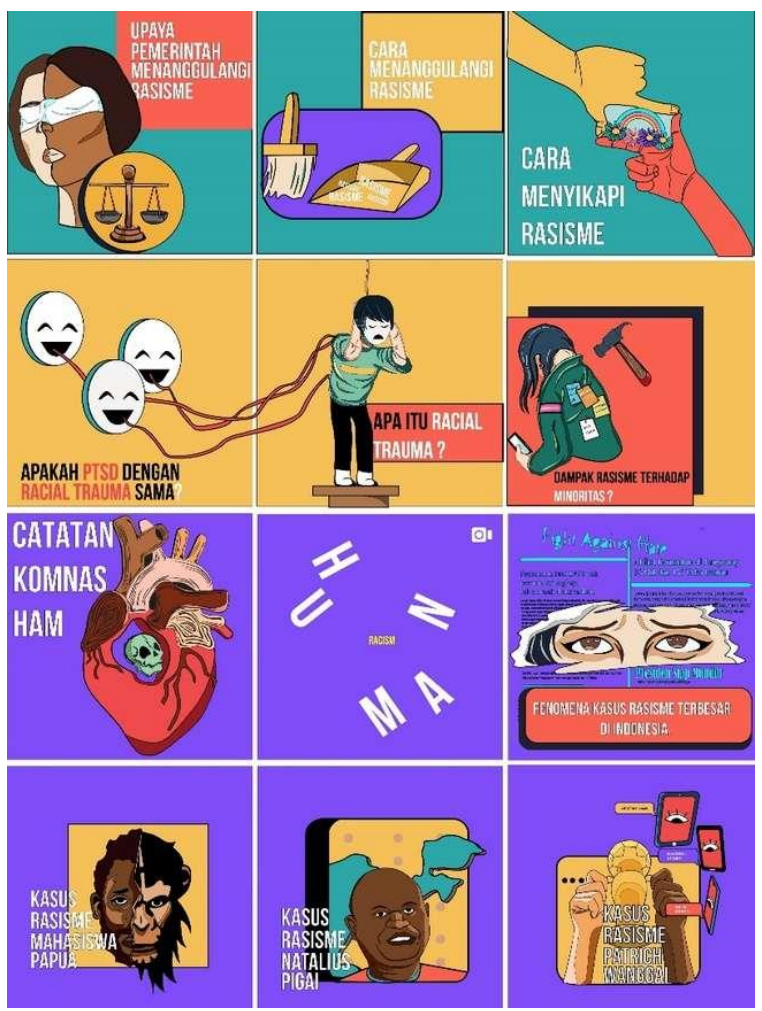

Gambar 3. Gambar desain feed Instagram feed 10-24 Sumber: Dokumentasi Penulis 


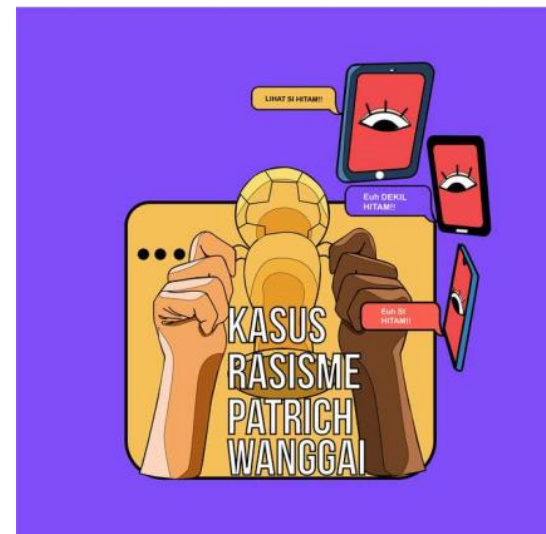

Gambar 4. Gambar detail feed Sumber: Dokumentasi Penulis

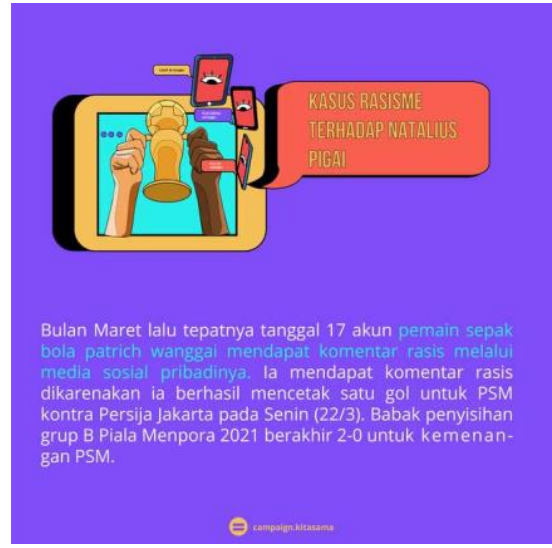

Gambar 5. Gambar detail feed Sumber: Dokumentasi Penulis

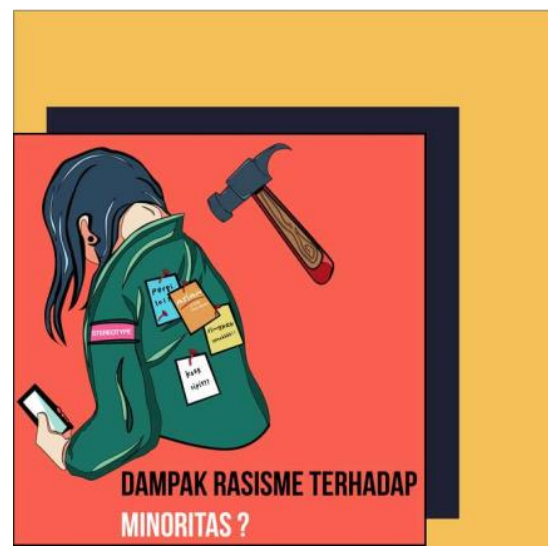

Gambar 6. Gambar detail feed Sumber: Dokumentasi Penulis 


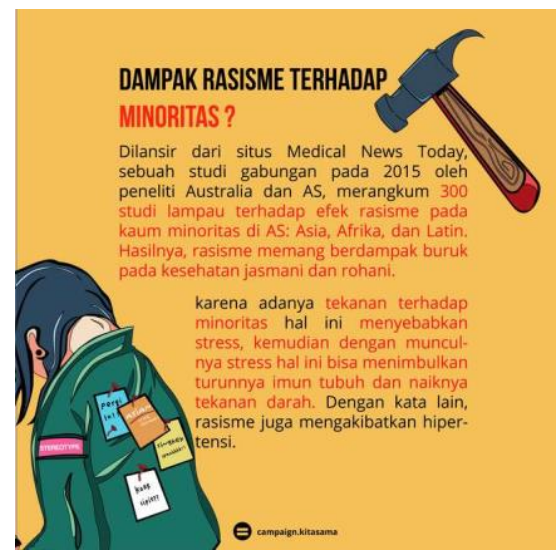

Gambar 7. Gambar detail feed Sumber: Dokumentasi Penulis

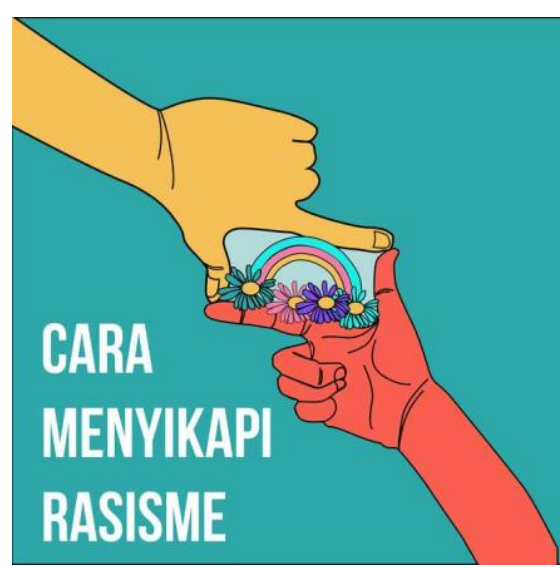

Gambar 8. Gambar detail feed Sumber: Dokumentasi Penulis

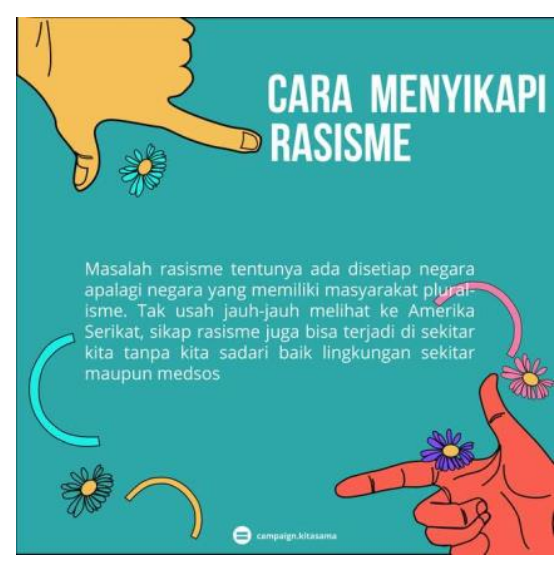

Gambar 9. Gambar detail feed Sumber: Dokumentasi Penulis 


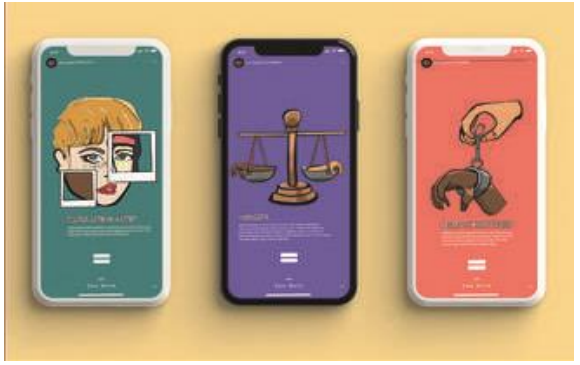

Gambar 10. Gambar Media Pendukung Story Ig Sumber: Dokumentasi Penulis

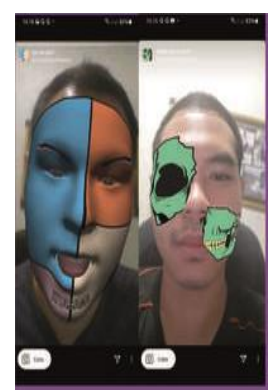

Gambar 11. Gambar Media Pendukung Filter Sumber: Dokumentasi Penulis

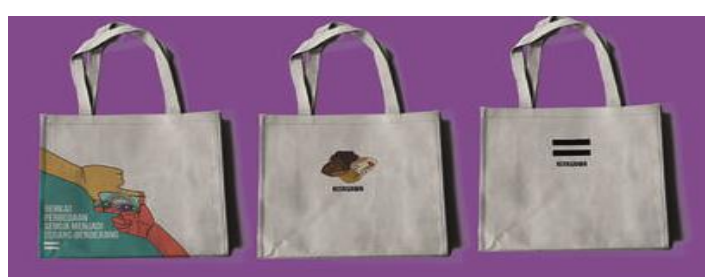

Gambar 12. Gambar Media Pendukung Totebag

Sumber: Dokumentasi Penulis

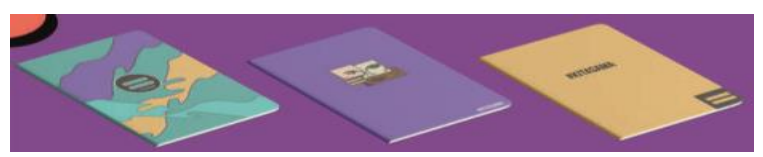

Gambar 13. Gambar Media Pendukung Notebook Sumber: Dokumentasi Penulis 


\section{SIMPULAN DAN SARAN}

\section{Simpulan}

Rasisme adalah sekumpulan dari berbagai ide serta kepercayaan yang memiliki potensi untuk membentuk suatu prasangka buruk yang pada akhirnya bisa membawa perilaku negatif terhadap kelompok masyarakat tertentu. Memiliki pemahaman mengenai rasisme dan sadar akan dampak negatif dari rasisme sangatlah penting mengingat masih ada tindakan rasisme terjadi di media sosial maupun diluar media sosial. Sehingga dengan bekal pengetahuan dan kesadaran akan tindakan rasisme, diharapkan dapat mengurangi tindakan rasisme yang ada saat ini.

Media kampanye yang berada di Instagram sering ditemukan hanya menggunakan sebuah foto dari fenomena yang terjadi. Berbeda dengan perancangan ini, dalam perancangan ini dibuat media kampanye rasisme berupa gambar konsep art dengan tambahan informasi seputar rasisme beserta pemahamannya dan contoh kasus, yang diupload ke dalam sosial media yaitu Instagram dikarenakan sosial media sering banyak digunakan oleh target audiens. Kemudian untuk media pendukung yang digunakan berupa Topi bucket, Masker, Baju, Pouch untuk baju, Totebag, Notebook, Tumbler, Sticker set, Filter Instagram, Story Instagram. Diharapkan dengan adanya kampanye sosial ini dapat meningkatkan kesadaran remaja diluar sana, bahwa tindakan rasisme bisa efek yang negatif bagi diri maupun orang disekitarnya dan juga sebagai upaya untuk membantu mengurangi tindakan rasisme yang terjadi di media sosial maupun diluar media sosial.

\section{Saran}

Berdasarkan kendala yang dialami saat proses perancangan, perlunya memahami studi kepustakaan, dan juga memikirkan konsep serta aset yang digunakan secara matang. Kemudian untuk karya disarankan ada penambahan interaksi pada target audience, seperti postingan untuk mini game, quiz di story Instagram dan masih banyak lagi interaksi- interaksi yang perlu ditambahkan untuk bisa membantu memberikan promosi kampanye. 


\section{DAFTAR PUSTAKA}

Abstract Reasoning WHO. 2015. Usia Remaja. (Diakses dari http://scholar.unand.ac.id/47346/2/BAB\%20I\%20PENDAHULUAN.pdf, pada tanggal 04 Desember 2020).

Adobe.com. What Is Vector Art? (Diakses dari https://www.adobe.com/sea/creativecloud/illustration/discover/vectorart.html, pada tanggal 04 Desember 16:30).

Anggriani S, Lia dan Kirana Nathalia. 2014. Desain Komunikasi Visual dasardasar panduan untuk pemula, Bandung: Nuansa Cendekia

Carrotacademy.com. Apa itu Concept art. (Diakses dari http://www.carrotacademy.com/apa-itu-concept-art/).

Conversation.com. 2020. Telah Lama Dunia Menghadapi Pandemi Rasisme. Bagaimana cara menghentikannya? (Diakses dari https://theconversation.com/telah-lama-dunia-menghadapi-pandemirasisme-bagaimana-cara-menghentikannya-140845, pada tanggal 13 Januari 13:30).

dgi.or.id. 2007. DeKaVe: Berkomunikasi Lewat Tanda. Diakses dari https://dgi.or.id/read/observation/dekave-berkomunikasi-lewat-tandavisual.html.

Indonesia.go.id. 2017. Suku Bangsa. (Diakses dari https://indonesia.go.id/profil/suku-bangsa, pada tanggal 12 Oktober jam 11:00)

Kajianpustaka.com. 2019. Pengertian, Teknik dan Jenis Kampanye. (Diakses dari https://www.kajianpustaka.com/2019/01/pengertian-jenis-dan-teknikkampanye.html pada tanggal, 13 Oktober $2020: 13: 25$ ).

KBBI.co.id. Arti Kata "Ras" KBBI. (Diakses dari https://www.kbbi.co.id/artikata/ras , pada tanggal 12 Januari 2021, 13:40)

Kompas.tv. 2020. Pengguna sosmed di Indonesia menurut "Digital Around The World 2020"

Merdeka.com. 2019. Polri Sebut Kasus Diskriminasi dan Rasisme Meningkat Terutama di Medsos. (Diakses dari https://www.merdeka.com/peristiwa/polri-sebut-kasus-diskriminasi-danrasisme-meningkat-terutama-di-medsos.html.

Merdeka.com. 2020. 5 Macam Ras di Indonesia, Ketahui Ciri dan Persebarannya.

Nationalgeographic.grid.id. Bagaimana Rasisme Terbentuk dan Bertahan di Masyarakat? (Diakses dari https://nationalgeographic.grid.id/read/132187873/bagaimana-rasismebisa-terbentuk-dan-bertahan-di-masyarakat?page=all, pada tanggal 13 Oktober 2020, 11:25).

Rustan, Surianto. 2020. Layout, Jakarta: CV. Nulisbuku Jendela Dunia

Seputarpengetahuan.co.id. Pengertian Ras Menurut Para Ahli.. (Diakses dari https://www.seputarpengetahuan.co.id/2017/09/16-pengertian-rasmenurut-para-ahli.html. pada tanggal 12 Januari 2021, 11:12).

Seputarilmu.com. 2020. Pengertian Typografi. (Diakses dari https://seputarilmu.com/2020/09/pengertian-tipografi.html. Pada tanggal 04 Desember 2020, 19:14) 